DOI: https://doi.org/10.24127/ajpm.v10i1.3177

\title{
MATHEMATICS LEARNING ACHIEVEMENT: DISCOVERY LEARNING COLLABORATION THINK PAIR SHARE VIEWED FROM REASONING
}

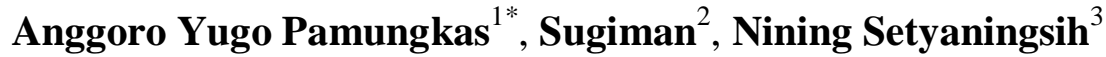 \\ ${ }^{1 *, 2}$ Mathematics Education, Universitas Negeri Yogyakarta, Yogyakarta, Indonesia \\ ${ }^{3}$ Mathematic Education, Universitas Muhammadiyah Surakarta, Surakarta, Indonesia \\ *Corresponding author \\ Email: anggoroyugo.2018@student.uny.ac.id ${ }^{1 *}$ \\ sugiman@uny.ac.id ${ }^{2)}$ \\ $\underline{\text { nining.setyaningsih@ums.ac.id }}^{3)}$
}

Received 20 October 2020; Received in revised form 14 March 2021; Accepted 31 March 2021

\begin{abstract}
This study aims to (1) analyze Discovery Learning Setting Think Pair Share on mathematics learning achievement, (2) analyze the level of students 'reasoning towards mathematics learning achievement, and (3) determine the interaction of Discovery Learning Setting Think Pair Share and the level of students' reasoning on mathematics learning achievement. This type of research uses quantitative research with a quasi-experimental design. All grade VIII students of State Junior High School 1 Sambi were the population of this study. The sample in this study consisted of two classes, 31 experimental and 32 control students, with a sampling technique using cluster random sampling. Data collection techniques using documentation, tests, and questionnaires. The data analysis technique used the ANOVA technique. Two ways with different cells. The results of the study with a significance level of $5 \%$ are (1) there is a good effect using Discovery Learning Setting Think Pair Share on students 'mathematics learning achievement, (2) there is a good effect of reasoning on students' mathematics learning achievement, and (3) there is no interaction between Discovery Learning. Think Pair Share setting and students' reasoning. Therefore, it is concluded that mathematics learning achievement can be influenced by Discovery Learning Setting Think Pair Share and reasoning.
\end{abstract}

Keywords: Discovery learning setting think pair share; mathematics learning outcomes; reasoning.

\begin{abstract}
Abstrak
Penelitian ini bertujuan untuk (1) menganalisis Discovery Learning Setting Think Pair Share terhadap prestasi belajar matematika, (2) menganalisis tingkat penalaran siswa terhadap prestasi belajar matematika, dan (3) mengetahui interaksi Discovery Learning Setting Think Pair Share dan tingkat penalaran siswa terhadap prestasi belajar matematika. Jenis penelitian menggunakan penelitian kuantitatif dengan desain quasi experiment. Seluruh siswa kelas VIII SMP Negeri 1 Sambi menjadi populasi penelitian ini. Sampel dalam penelitian ini terdiri dari dua kelas dengan 31 siswa eksperimen dan 32 siswa kontrol, dan pengambilan teknik sampling menggunakan cluster random sampling. Teknik pengumpulan data menggunakan metode dokumentasi, tes dan angket. Teknik analisis data menggunakan teknik ANAVA dua jalan dengan sel tak sama. Hasil penelitian dengan tingkat signifikansi 5\% adalah (1) ada pengaruh baik menggunakan Discovery Learning Setting Think Pair Share terhadap prestasi belajar matematika siswa, (2) ada pengaruh baik penalaran terhadap prestasi belajar matematika siswa, dan (3) tidak ada interaksi antara Discovery Learning Setting Think Pair Share dan penalaran siswa. Oleh karena itu, disimpulkan bahwa prestasi belajar matematika dapat dipengaruhi oleh Discovery Learning Setting Think Pair Share dan penalaran.
\end{abstract}

Kata kunci: Discovery learning setting think pair share; penalaran; prestasi belajar matematika.

This is an open access article under the Creative Commons Attribution 4.0 International License 


\section{INTRODUCTION}

Mathematics is very useful because it can help the mastery of other sciences, both from the development of related sciences and in their application in everyday life. But the benefits of mathematics are often overlooked, people find maths difficult and scary. Even though in everyday life applications, mathematics is widely used.

In the process of learning mathematics, learning achievement has an important role, because the higher the change in mathematics produced, the more effective the mathematics learning process will be. However, in reality, mathematics learning achievement tends not to meet expectations. Based on the published survey results from the Program for International Student Assessment (PISA) (OECD, 2018), Indonesia has experienced ups and downs in scores and is still below the average score. Indonesia ranks 72 nd with an average math score of 379 . Compared to the average PISA score of 489 in member countries of the Organization for Economic Cooperation and Development (OECD), Indonesia's score is low.

In addition to the PISA survey, it can also be seen from the mathematics national exam scores taken from the Ministry of Education and Culture's data. The average score of junior high school mathematics examination results for 2015-2019 is always the lowest compared to other subjects. Then the recapitulation of the results of the 2016 National Examination of the student's achievement of the Sambi 1 State Junior High School was included in the low category. This can be seen from the average acquisition of the results of the National Examination for Mathematics for Junior High School 1 Sambi, which is 46.15 compared to the average score of all junior high school levels, namely 49.84. Besides, the average mathematics test subjects were the lowest compared to other examinations such as Science, Indonesian and English. Taking into account the results of these exams, it shows that the mathematics learning achievement of students of the Sambi 1 State Junior High School needs efforts to be improved.

Mathematics learning achievement is still low, influenced by several factors from within and outside the students. One of the factors causing the low achievement in learning mathematics is the students' poor reasoning. The National Council of Teachers of Mathematics (NCTM, 2000) released a statement that teachers must pay attention to five mathematical abilities in the implementation of mathematics learning, one of the five things is the ability to reason (reasoning). (Rosnawati, 2013) revealed that the cognitive domain, especially the reasoning of Indonesian students, is still low with a percentage of $17 \%$ below the international average of $30 \%$. (Riyanto \& Siroj, 2011) states that one of the causes of low reasoning ability is that the learning applied by the teacher in the classroom does not involve students in learning or there is no discussion between students and teachers. Therefore, it is necessary to learn mathematics which is innovative, and is able to increase the self-potential and ability of students in reasoning.

The Discovery Learning model is an alternative that can be used to improve mathematics learning achievement and mathematical reasoning. In the 2013 Curriculum, Discovery Learning model forces 
students to be active in learning and learning is not judged only by results, but on the learning process. In (Suminar \& Meilani, 2016) research, Discovery Learning can improve student learning achievement. Another study, (Sutrisno et al., 2020) states that learning achievement using Discovery Learning model is better than conventional learning models. Then the results of research by (Zubainur et al., 2020) state that the application of learning using the Discovery Learning model can make students' varied mathematical reasoning.

For Discovery Learning model to be easier to control, students must be grouped into discussion spaces. One group discussion that can be applied is to use Think Pair Share strategy. (Rosita \& Leonard, 2015) states that Think Pair Share provides an opportunity to think in solving a problem and cooperate with peers or share knowledge in the form of small group discussions so that all students are active in teaching and learning activities. (Jatmiko, 2015) Think Pair Share modified with a module has better performance than just Think Pair Share. (Hafizhah et al., 2019) The mathematics learning achievement of students using Think Pair Share learning model is better than students who are taught using conventional learning. (Simanjuntak, 2020) in the results of his research stated that the use of the Think Pair Share learning model made the mathematical reasoning of seventhgrade junior high school students experience an increase from a poor category to a good category.

To achieve learning objectives, it is necessary to modify the learning model. (Iskandar \& Leonard, 2019) states that innovation in implementing learning using a learning model that is following the material being taught needs to be held. Another opinion (Anas et al., 2013) states that the difficulties felt by students need to be given a modification of the learning model, to arouse and involve students' discipline in learning.

However, in practice, teachers rarely modify the learning model, this can be seen from the number of teachers who provide direct instruction, because it is more time-efficient, practical, and not difficult to implement. Therefore, Discovery learning model and Think Pair Share strategy can be an alternative to achieve learning objectives, such as training students to be active and able to cooperate with their friends when solving math problems. So, the modification of the learning model that can be applied is Discovery Learning Setting Think Pair Share. The application of modified models and strategies is expected to provide opportunities for students to use their reasoning in the learning process so that it will have a positive effect on mathematics learning achievement.

The purpose of this research is that (1) can analyze and test the effect of Discovery Learning Setting Think Pair Share model on mathematics learning achievement, (2) can analyze and test the effect of students' level of reasoning on mathematics learning achievement, and (3) can analyze and test interactions Discovery Learning Setting Think Pair Share model and students' level of reasoning towards mathematics learning achievement.

Based on the explanation of these objectives, three hypotheses can be formulated, namely (1) the influence of Discovery Learning Setting Think Pair Share model on mathematics learning achievement, (2) the influence of students' level of reasoning on mathematics learning achievement, and 
DOI: https://doi.org/10.24127/ajpm.v10i1.3177

(3) the interaction of Discovery Learning model. Think Pair Share setting and students' level of reasoning on mathematics learning achievement.

\section{METHODS}

This type of research is included in quantitative research. This research design used a quasi-experiment with posttest only type and nonequivalent control group design. The total population in this study was all students of class VIII of Sambi 1 State Junior High School in the academic year 2016/2017 as many as 216 students. The sampling technique used cluster random sampling and obtained an experimental sample of 31 students in class VIII C and a control sample of 32 students in class VIII D. Before the sample class was given treatment, the sample would be subjected to a balance test to ensure whether the sample had a balanced initial ability. The experimental class was given learning using Discovery Learning Setting Think Pair Share model, while the control class was given learning using the conventional model.

Data collection techniques used in this study include documentation, questionnaires, and tests. The documentation method is used to obtain data on students 'initial ability in the form of class VIII students' Semester Final Examination scores. The data is then carried out a balance test before the two sample classes are given treatment, the balance test uses the t-test. Question description as a test instrument is used to obtain data on mathematics learning achievement and reasoning questionnaires as a questionnaire instrument are used to obtain reasoning data. The sample class was given a test instrument and a questionnaire, then tested it to find out whether the instrument was valid and reliable. The formula used to test the validity of the instrument uses the Pearson correlation formula/Product Moment and the instrument reliability test uses the Alpha formula.

The data analysis technique used was the two-way ANAVA test statistical technique with different cells with an error rate of $5 \%$. Before the data analysis test, a prerequisite test is first carried out to test whether the sample comes from a normally distributed population or not, namely, the normality test using the Lilliefors method. Then, the population variance homogeneity test was carried out to test the sample from a homogeneous population or not using the Bartlett method. If the ANOVA results of two different cell paths show the hypothesis $\mathrm{H}_{0}$ is rejected, it will be followed by a multiple comparison test using the Scheffe method, where this further test is to determine the effectiveness of the two learning strategies.

\section{RESULTS AND DISCUSSION}

Before being given treatment, the experimental class with Discovery Learning Setting Think Pair Share model and the control class with the conventional learning model were given a balance test treatment, where the results showed that the experimental class and the control class had a balanced initial ability. The data used for the balance test were the odd semester final examination scores for the experimental class and the control class for the 2016/2017 academic year. Based on the results of the calculation of the balance test with the t-test, obtained $\mathrm{t}_{\text {count }}=1.636$ and $\mathrm{t}_{\text {table }}=1.999$ with a significant level of $5 \%$. Because $\mathrm{t}_{\text {count }}<\mathrm{t}_{\text {table }}$ means that $\mathrm{H}_{0}$ is accepted, and it can be concluded that before 
being given the treatment, the experimental class and the control class had equal initial mathematical abilities.

The mathematics learning achievement test instrument consisted of 5 description questions and a reasoning questionnaire instrument consisting of 30 tested items. Before the sample class is given a test instrument and a questionnaire, first the test and questionnaire instruments are validated and tested in a class other than the sample class. Through the two validators, the mathematics learning achievement test instrument experienced several improvements. Furthermore, the mathematics learning achievement test instrument and the reasoning questionnaire instrument were tested on 61 students in the nonsample class. The test results of the mathematics learning achievement test instrument stated that 5 overall questions were valid, and the reasoning questionnaire instrument obtained 24 valid items from a total of 30 statements. The research instrument that has been valid, then the reliability test is carried out. The results of the calculation of the reliability test on 5 items of mathematics learning achievement test items showed that the value of $r_{11}=0.843>0.7$, which means that the 5 items of the test items were declared reliable, and the results of the calculation of the reliability test on the 24 items of the reasoning questionnaire statement showed that the value of $\mathrm{r}_{11}=$ $0.847>0.7$ which means that the 24 question items are reliable. After the two research instruments are declared valid and reliable, the research instrument can be given to the research sample.

The mathematics learning achievement data and the reasoning data that have been obtained are then carried out the prerequisite analysis test, namely the normality test and the homogeneity test with an error rate of $5 \%$. The summary of the results of the normality and homogeneity tests can be seen in Table 1 and Table 2.

Table 1. Summary of normality test results.

\begin{tabular}{ccccc}
\hline Source & Class Test & $\mathbf{L}_{\text {count }}$ & $\mathbf{L}_{\text {table }}$ & Conclusion \\
\hline Mathematics & Experiment & 0,074 & 0,159 & Normal \\
Learning Outcomes & Control & 0,088 & 0,156 & Normal \\
Mathematical & High & 0,155 & 0,213 & Normal \\
Reasoning & Medium & 0,138 & 0,167 & Normal \\
& Low & 0,096 & 0,195 & Normal \\
\hline
\end{tabular}

Table 2. Summary of homogeneity test results.

\begin{tabular}{cccc}
\hline Source & $\boldsymbol{\chi}_{\text {obs }}^{2}$ & $\chi_{\text {table }}^{2}$ & Information \\
\hline $\begin{array}{c}\text { Learning model } \\
\left(\mathrm{A}_{1}\right) \text { and }\left(\mathrm{A}_{2}\right)\end{array}$ & 1,253 & 3,841 & Homogeneous \\
$\begin{array}{c}\text { Mathematical Reasoning } \\
\left(\mathrm{B}_{1}\right),\left(\mathrm{B}_{2}\right) \text {, and }\left(\mathrm{B}_{3}\right)\end{array}$ & 4,542 & 5,991 & Homogeneous \\
\hline
\end{tabular}

The results of the normality test show that $\mathrm{H}_{0}$ is accepted, so this indicates that the study sample comes from a normally distributed population. While the homogeneity test results show that $\mathrm{H}_{0}$ is accepted, this indicates 
that the sample comes from a homogeneous population.

Based on this description, it shows that the analysis prerequisite test is met, where the two samples are in a balanced state, normally distributed, and homogeneous. Furthermore, the hypothesis testing stage can be carried out using two-way ANOVA of different cells at an error rate of $5 \%$. The recapitulation of the ANOVA calculation results for two different cell paths can be presented in Table 3 .

Table 3. Recapitulation of ANOVA two different cell paths.

\begin{tabular}{ccccccc}
\hline Source & JK & dK & RK & $\mathbf{F}_{\text {obs }}$ & $\mathbf{F}_{\boldsymbol{\alpha}}$ & Results \\
\hline Learning model (A) & 118,38 & 1 & 118,38 & 4,83 & 4,01 & $\mathrm{H}_{0}$ rejected \\
Reasoning (B) & 440,43 & 2 & 220,21 & 8,99 & 3,08 & $\mathrm{H}_{0}$ rejected \\
Interaction (AB) & 102,85 & 2 & 51,43 & 2,09 & 3,08 & $\mathrm{H}_{0}$ received \\
Error (G) & 1396,54 & 57 & 24,5 & - & - & - \\
Total (T) & 2058,2 & 62 & - & - & - & - \\
\hline
\end{tabular}

Based on Table 3, it can be concluded that, there is an influence between Discovery Learning Setting Think Pair Share model on mathematics learning achievement.

ANOVA results of two unequal cell paths with an error rate of $5 \%$ were obtained $\mathrm{F}_{\mathrm{A}}=4,83>\mathrm{F}_{0,05 ; 1 ; 57}=4,01$ then $\mathrm{H}_{0 \mathrm{~A}}$ is rejected, the meaning that there is an influence of the learning model on mathematics learning achievement. Because in this study there are two learning models, namely Discovery Learning Setting Think Pair Share model and the conventional learning model, so for further testing there is no need to do double comparisons between lines. To find out which learning model is better, it is only enough to compare the marginal mean of each learning model. The summary of the inter-cell mean and marginal mean is shown in Table 4.

Table 4. Summary of intercellular mean and marginal mean

\begin{tabular}{ccccc}
\hline Learning Model & \multicolumn{3}{c}{ Reasoning } & Marginal \\
\cline { 2 - 4 } & High & Medium & Low & \\
\hline Discovery Learning Setting & 90,6 & 83,4 & 80,7 & 84,9 \\
Think Pair Share & 84,6 & 81,8 & 76,5 & 80,9 \\
Conventional & 87,6 & 82,6 & 78,6 & \\
Marginal Mean & &
\end{tabular}

Based on the marginal mean of Table 4, it is obtained that the marginal mean of mathematics learning achievement with Discovery Learning Setting Think Pair Share model is 84.9, while the marginal average value of mathematics learning achievement using the conventional learning model is 80.9. Thus, it can be concluded that students 'mathematics learning achievement using Discovery Learning Setting Think Pair Share model is better than students' mathematics learning achievement using the conventional learning model.

This is also supported by conditions that occur in the field, in conventional learning models that are 
still teacher-centered, learning becomes less attractive as a result of which students are less actively involved in learning. Besides, teachers often do not come to class during class hours, so this causes students to receive less guidance and assistance from teachers in learning. While the learning process uses Discovery Learning Setting Think Pair Share model, students look active, creative, and confident. During the learning process, students are allowed to try to find their own solutions to the problems given by the teacher through discussions between pairs, so that students are directly involved in the learning process. In every opportunity, students also ask questions related to material that is considered difficult.

This is in line with previous research that has been conducted (Burais et al., 2016) which states that by using Discovery Learning model students are alloowed to learn actively, where students are guided and directed in carrying out learning activities according to their objectives. In line with Burais, this condition is in line with previous research conducted by (Maarif, 2016) which stated that the improvement of the students' mathematical analogical ability using Discovery Learning method is considered better than the expository group.
In addition, this condition is also in line with the research conducted (Husna \& Fatimah, 2013) which states that the mathematical problem-solving abilities of students who obtain ThinkPair-Share type of cooperative learning model are better than students who receive conventional learning. Based on these descriptions, it can be concluded that there is an influence of the learning model on the mathematics learning achievement of class VIII students on the subject of circumference and circle area.

a. There is an effect of mathematics learning achievement in terms of reasoning.

Using ANOVA two different cell paths at an error rate of $5 \%$ were obtained $\mathrm{F}_{\mathrm{B}}=8,99>\mathrm{F}_{0,05 ; 2 ; 57}=3,08$ then it can be decided $\mathrm{H}_{0 \mathrm{~B}}$ is rejected. This means that there is an effect of reasoning on mathematics learning achievement. Because $\mathrm{H}_{0 B}$ is rejected, it is necessary to do a further test, namely the multiple comparison test between columns. The comparison test aims to determine whether there is a difference in the average mathematics learning achievement between students who have high, medium, and low categories of reasoning. The result of comparison test can be seen in Table 5 .

Table 5. Comparison test of mean between columns.

\begin{tabular}{ccccc}
\hline $\boldsymbol{H}_{\boldsymbol{0}}$ & $\boldsymbol{H}_{\boldsymbol{1}}$ & $\boldsymbol{F}_{\text {count }}$ & $\mathbf{2 F}_{\text {table }}$ & Results \\
\hline$\mu_{.1}=\mu_{.2}$ & $\mu_{.1} \neq \mu_{.2}$ & 12,67 & 6,16 & $\mathrm{H}_{0}$ rejected \\
$\mu_{.1}=\mu_{.3}$ & $\mu_{.1} \neq \mu_{.3}$ & 36,64 & 6,16 & $\mathrm{H}_{0}$ rejected \\
$\mu_{.2}=\mu_{.3}$ & $\mu_{.2} \neq \mu_{.3}$ & 22,80 & 6,16 & $\mathrm{H}_{0}$ rejected \\
\hline
\end{tabular}

Based on Table 5 it is obtained $\mathrm{F}_{1}$. ${ }_{2}=12,67>\mathrm{F}_{\text {table }}=6,16$, it can be concluded $\mathrm{H}_{0}$ is rejected, it means that there is a significant effect of mathematics learning achievement between students who have high 
category reasoning and students who have moderate category reasoning. $\mathrm{F}_{1-3}$ $=36,64>\mathrm{F}_{\text {table }}=6,16$ it can be concluded $\mathrm{H}_{0}$ is rejected, it means that there is a significant effect of mathematics learning achievement between students who have high category reasoning and students who have low category reasoning. $\mathrm{F}_{2-3}=$ $22,80>F_{\text {table }}=6,16$ it can be concluded $\mathrm{H}_{0}$ is rejected, it means that there is a significant effect of mathematics learning achievement between students who have moderate category reasoning and students who have low category reasoning.

In line with the results of data analysis in this study, the marginal mean of mathematics learning achievement with high reasoning was 87.6, while the marginal mean value of mathematics learning achievement with moderate reasoning was 82.6 , and the marginal mean value of mathematics learning achievement with low category reasoning was 78. , 6. This is supported by conditions in the field where students' reasoning varies, some are classified as high, medium, and low. A significant effect can be seen from students who have high and low category reasoning. Students who have high category reasoning are better able to present mathematical statements, propose assumptions, manipulate mathematics, compile evidence, draw conclusions and validate mathematical problems. Meanwhile, students who have low category reasoning have difficulty solving math problems given by the teacher, and sometimes ignore the mathematics learning process so that there is no habit and follow-up to solve math problems. This is in line with the results of research (Sumartini, 2015) which states that reasoning helps students to conclude and prove a statement, build new ideas, to solve problems in mathematics. Therefore, reasoning must always be used and developed in every mathematics learning.

Based on this description, it can be concluded that there is an influence between reasoning and mathematics learning achievement of class VIII students on the subject of circumference and circle area.

b. There is an interaction of learning models and the level of reasoning on mathematics learning achievement.

Using ANOVA two different cell paths at an error rate of $5 \%$ were obtained $\quad \mathrm{F}_{\mathrm{AB}}=2,09<\mathrm{F}_{0,05 ; 2 ; 57}=$ 3,08 it can be concluded $\mathrm{H}_{0 \mathrm{AB}}$ is received. This means that there is no interaction between learning models and reasoning on mathematics learning achievement. This condition can be presented in the form of a learning model variable image as follows.

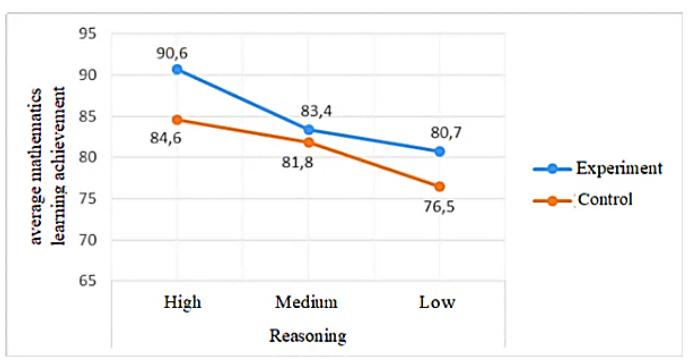

Figure 1. Variable graphics of learning and reasoning models.

The presence or absence of interaction can also be seen from Figure 1 on the graph of the variable effect profile of the learning model, it can be seen that the two lines representing the learning model applied to the experimental class and the control class does not intersect or touch.

It is known that the experimental class uses Discovery Learning Setting Think Pair Share model and the control 
class uses the conventional learning model. In each learning model, the mathematics learning achievement of students who have high category reasoning is better than students who have moderate category reasoning and low categories. In addition to the high, medium, and low categories of student reasoning, Discovery Learning Setting Think Pair Share model provides better mathematics learning achievement than conventional learning models. Therefore, it can be concluded that there is no interaction between the learning model and reasoning on the mathematics learning achievement of class VIII students on the circumference and area of the circle.

There is no interaction between learning models and student reasoning on the mathematics learning achievement because there are various factors that are contained within the students themselves, for example, activeness, independence, interest, motivation, and so on which are not examined by researchers. This is due to the limited time the researcher has, so the researcher cannot reach various factors that can affect mathematics learning achievement, so the expected interaction does not exist.

This is in line with research by (Sutrisno et al., 2020) which states that learning achievement using Discovery Learning model is better than conventional learning models. Then (Hafizhah et al., 2019) students' mathematics learning achievement using Think Pair Share learning model is better than students taught using conventional learning. (Rahman et al., 2019) there is no interaction between the learning model and the initial capability on students' mathematical reasoning abilities.
Based on these descriptions, the selection of the right learning model greatly affects the mathematics learning achievement obtained by students. Mathematics learning achievement taught by collaborating with Discovery Learning Setting Think Pair Share model is better than taught using the conventional model. This is supported by students' reasoning when learning using Discovery Learning Setting Think Pair Share model, students are more active and conducive in pair discussions to solve problems on the given Student Worksheets. The application of this model can also minimize the time involved in forming groups.

Therefore, Discovery Learning Setting Think Pair Share model can be applied by teachers in the learning process as an effort to improve student learning achievement. The results of this study can be used as a reference in selecting the appropriate learning model to improve mathematics learning achievement.

\section{CONCLUSION AND SUGGESTION}

Based on data analysis and discussion, it can be concluded that there is an influence of Discovery Learning Setting Think Pair Share model on mathematics learning achievement. Mathematics learning achievement using Discovery Learning Setting Think Pair Share model is better than the conventional learning model. Furthermore, there is the effect of reasoning on mathematics learning achievement. The mathematics learning achievement of students who have high reasoning is better than students who have moderate and low reasoning. There is no interaction between learning models and students' reasoning on mathematics learning achievement. The suggestions for further relevant 
research, namely online learning using a modified learning model that is more suitable during the Covid-19 pandemic.

\section{REFERENCES}

Anas, M., Kusmayadi, T. A., \& Suyono, S. (2013). Eksperimentasi Model Pembelajaran Think Pairshare Modifikasi Penemuan Terbimbing Berbantuan Microsoft Power Point Pada Pembelajaran Matematika Ditinjau dari Kedisiplinan Belajar. Jurnal Pembelajaran Matematika, $1(3)$.

Burais, L., Ikhsan, M., \& Duskri, M. (2016). Peningkatan Kemampuan Penalaran Matematis Siswa melalui Model Discovery Learning. Jurnal Didaktik Matematika, 3(1), 77-86.

Hafizhah, N., Isnani, I., \& Suwandono, S. (2019). Keefektifan Model Pembelajaran TPS terhadap Motivasi, Kemampuan Berpikir Kritis, dan Prestasi Belajar Matematika. JPMP (Jurnal Pendidikan MIPA Pancasakti), 3(1), 61-67.

Husna, M., \& Fatimah, S. (2013). Peningkatan kemampuan pemecahan masalah dan Komunikasi matematis siswa Sekolah Menengah Pertama melalui model pembelajaran kooperatif tipe Think-pair-share (TPS). Jurnal Peluang, 1(2), 8192.

Iskandar, A. P., \& Leonard, L. (2019). Modifikasi Model Pembelajaran Tipe Numbered Heads Together (NHT) dengan Strategi Pembelajaran Tugas dan Paksa Terhadap Kemampuan Penalaran Matematika Siswa. Jurnal Mercumatika: Jurnal Penelitian Matematika dan Pendidikan Matematika, 4(1), 1-13.
Jatmiko, J. (2015). Eksperimen model pembelajaran think-pair-share dengan modul (TPS-M) terhadap prestasi belajar matematika ditinjau dari minat belajar. JIPM (Jurnal Ilmiah Pendidikan Matematika), 3(2).

Maarif, S. (2016). Improving Junior High School Students' Mathematical Analogical Ability Using Discovery Learning Method. International Journal of Research in Education and Science, 2(1), 114-124.

NCTM, N. (2000). Principles and Standards for School Mathematics.

OECD. (2018). Programme for International Student Assessment (PISA) Results From PISA 2018 (hal. 1-10).

Rahman, L., Fitraini, D., \& Fitri, I. (2019). Pengaruh Penerapan Model Discovery Learning terhadap Kemampuan Penalaran Matematis Ditinjau dari Pengetahuan Awal Siswa SMP Negeri 3 Tambang Kabupaten Kampar. JURING (Journal for Research in Mathematics Learning), 2(1), 110.

Riyanto, B., \& Siroj, R. A. (2011). Meningkatkan kemampuan penalaran dan prestasi matematika dengan pendekatan konstruktivisme pada siswa sekolah menengah atas. Jurnal Pendidikan Matematika, 5(2), 111-128.

Rosita, I., \& Leonard, L. (2015). Meningkatkan kerja sama siswa melalui pembelajaran kooperatif tipe Think Pair Share. Formatif: Jurnal Ilmiah Pendidikan MIPA, 3(1).

Rosnawati, R. (2013). Kemampuan penalaran matematika siswa SMP Indonesia pada TIMSS 2011. In 
DOI: https://doi.org/10.24127/ajpm.v10i1.3177

Prosiding Seminar Nasional

Penelitian, Pendidikan dan

Penerapan MIPA, Fakultas MIPA,

Universitas Negeri Yogyakarta

(Vol. 18, hal. 1-6).

Simanjuntak, A. S. (2020). Efektivitas

Model Pembelajaran Think Pair

Share Terhadap Kemampuan

Penalaran Matematis Siswa Di

SMP Swasta HKBP

Padangsidimpuan. JURNAL

MathEdu (Mathematic Education

Journal), 3(2), 89-96.

Sumartini, T. S. (2015). Peningkatan

Kemampuan Penalaran Matematis

Siswa melalui Pembelajaran

Berbasis Masalah. Jurnal

Pendidikan Matematika, 5(1), 110.

Suminar, S. O., \& Meilani, R. I. (2016). Pengaruh model pembelajaran discovery learning dan problem based learning terhadap prestasi belajar peserta didik. Jurnal Pendidikan Manajemen Perkantoran (JPManper), 1(1), 80-89.
Sutrisno, S., Happy, N., \& Susanti, W. (2020). Eksperimentasi Model Discovery Learning Terhadap Prestasi dan Minat Belajar Matematika Siswa. AKSIOMA: Jurnal Program Studi Pendidikan Matematika, 9(3), 580-590.

Zubainur, C. M., Jannah, R., Syahjuzar, S., \& Veloo, A. (2020). Kemampuan Penalaran Matematis Siswa Melalui Model Discovery Learning Di Sekolah Menengah Aceh. JURNAL SERAMBI ILMU, 21(1), 148-170. 